\title{
SELECT BIBLIOGRAPHY OF RECENT BOOKS ON AUGUSTINE
}

Brown, Peter. Augustine of Hippo: A Biography. Berkeley: University of California, 1967.

Bubacz, Bruce. St. Augustine's Theory of Knowledge: A Contemporary Analysis. New York: Edwin Mellin, 198i.

Chadwick, Henry. Augustine. Oxford: Oxford University Press, 1986.

Clark, Mary T. Augustine. Washington, D.C.: Georgetown University Press, 1994.

Elshtain, Jean Bethke. Augustine and the Limits of Politics. Notre Dame, Ind.: Notre Dame University Press, 1995 .

Hölscher, Ludger. The Reality of the Mind: St Augustine's Arguments for the Human Soul as a Spinitual Substance. London: Routledge and Kegan Paul, 1986.

Kirwan, Christopher. Augustine. Arguments of the Philosophers. London: Routledge, I989.

Markus, Robert A. Augustine: A Collection of Critical Essays. Garden City, N.Y.: Doubleday, 1972.

Matthews, Gareth B. Thought's Ego in Augustine and Descartes. Ithaca: Cornell University Press, 1992.

O'Connell, Robert J. The Origin of the Soul in St. Augustine's Later Works. New York: Fordham University Press, 1987.

O'Daly, Gerard. Augustine's Philosophy of Mind. London: Duckworth, I987.

Rist, John M. Augustine: Ancient Thought Baptized. Cambridge: Cambridge University Press, I994.

Stock, Brian. Augustine the Reader: Meditation, Self-Knowledge, and the Ethics of Interpretation. Cambridge, Mass.: Harvard University Press, 1996.

Wetzel, James. Augustine and the Limits of Virtue. Cambridge: Cambridge University Press, I992. 
